\title{
Contribution to Research on Securitization: Assessment of SCI and SSCI Articles from 1996 To 2012
}

\author{
King Jeng LU ${ }^{3}$, Tainyi LUOR ${ }^{1}$, Liang CHIUNG-JU², Hsi-peng LU ${ }^{3}$ \\ ${ }^{1}$ Graduate School of Management, National Taiwan University of Science \& Technology \\ Taipei, Taiwan, R.O.C \\ ${ }^{2}$ Graduate Institute of Finance, National Taiwan University of Science \& Technology, \\ Taipei, Taiwan, R.O.C. \\ ${ }^{3}$ Department of Information Management, National Taiwan University of Science \& \\ Technology, Taipei, Taiwan, R.O.C. \\ lu935633277@gmail.com,dr.luor@gmail.com, cjliang@mail.ntust.edu.tw, \\ hsipeng@cs.ntust.edu.tw
}

We conducted a study to gauge trends and contributions to the broad field of securitization. This article reviews 365 academic articles on securitization that were published in 47 Social Sciences Citation Index journals from 1996 to June 2012. We identified keywords and searched and determined related articles in the ISI Web of Science database. Our findings included the number of publications per year, categories of article types, main academic journals and authors, and most-cited articles. The citation counts for authors, journals, and articles were also analyzed. Results indicated that the number of articles related to the keyword "securitization" increased from 1996 to 2012, which suggests an upward trend in the influence of securitization. We also determined that "securitization" research fascinated numerous scholars during the 16-year period. In particular, researchers from the USA, Europe, Canada, and Asia contributed most to this field. This literature review provides evidence that the "securitization" concept has attracted academic researchers, which results in significant contributions to the field of entrepreneurial research. The findings in this study can help authors in future development of securitization.

Keywords: Securitization, Literature Review, Contribution to Research

1 Introduction

Securitization is the financial practice of pooling various types of contractual debt, such as commercial mortgages, residential mortgages, credit card debt obligations, or auto loans, and selling the said consolidated debts as bonds, pass-through securities, or collateralized mortgage obligations (CMOs) to various investors. Securitization also encompasses the principal and interest on the debt underlying the security and is commonly paid back to the diverse investors. Securities backed by mortgage receivables are called mortgage-backed securities (MBS), and those backed by other types of receivables are asset-backed securities (ABS). Although numerous studies focus on securitization research, little is known on the stream of securitization research. This study attempts to examine the trends and contribution in the securitization field by surveying 365 securiti- zation articles that appeared in 47 journals from 1996 to 2012.

In recent years, the academe has observed the increasing significance of indices, such as the Sciences Citation Index (SCI) and Social Sciences Citation Index (SSCI). Therefore, the assessment of the researchers' and individual publications' effect factors on their individual fields is possible. SCI and SSCI contain collective bibliography sections of selected prestigious academic journals. Each time a reference found in the bibliography of an SCI- or SSCI- weighted journal is cited by another author, its "impact factor" is calculated. This study aims to distinguish the active players in the study of securitization. It also aims to evaluate their "contributions" and the number of times that they have published and has been cited by other authors, as declared by the ISI Web of Science (WOS) database. 
In the field of academic inquiry, Zou [15] examined the literature related to advertisement. Latchem [11] adopted content analysis to quantify the foci and occurrence of topics published in the British Journal of Educational Technology between 2000 and November 2005. Luor et al. [12] assessed the literature on computer-assisted learning, and and MacArthur et al. [13] traced the use of technology in teaching disabled students.

Pertinent literature in the securitization field is also elicited considerable research attention. Cooley and Heck [4] published an article entitled "Significant Contributions to Finance Literature, Financial Management (pre-1986)." Heck, Cooley, and Hubbard [10] also carried out a survey on the contributing authors and institutions in the Journal of Finance from 1946 to 1985. Graves, Randall, and Marchand [9] published an article entitled "Economics Departmental Rankings: Research Incentives, Constraints, and Efficiency." Moreover, studies on contributors to securitization journals provide objective measures of productivity in securitization. Sa-Aadu and Shilling [14] found that the rankings of contributing authors to the AREUEA Journal are categorized according to the origins of their doctoral degrees and their employers from 1973 to 1987.

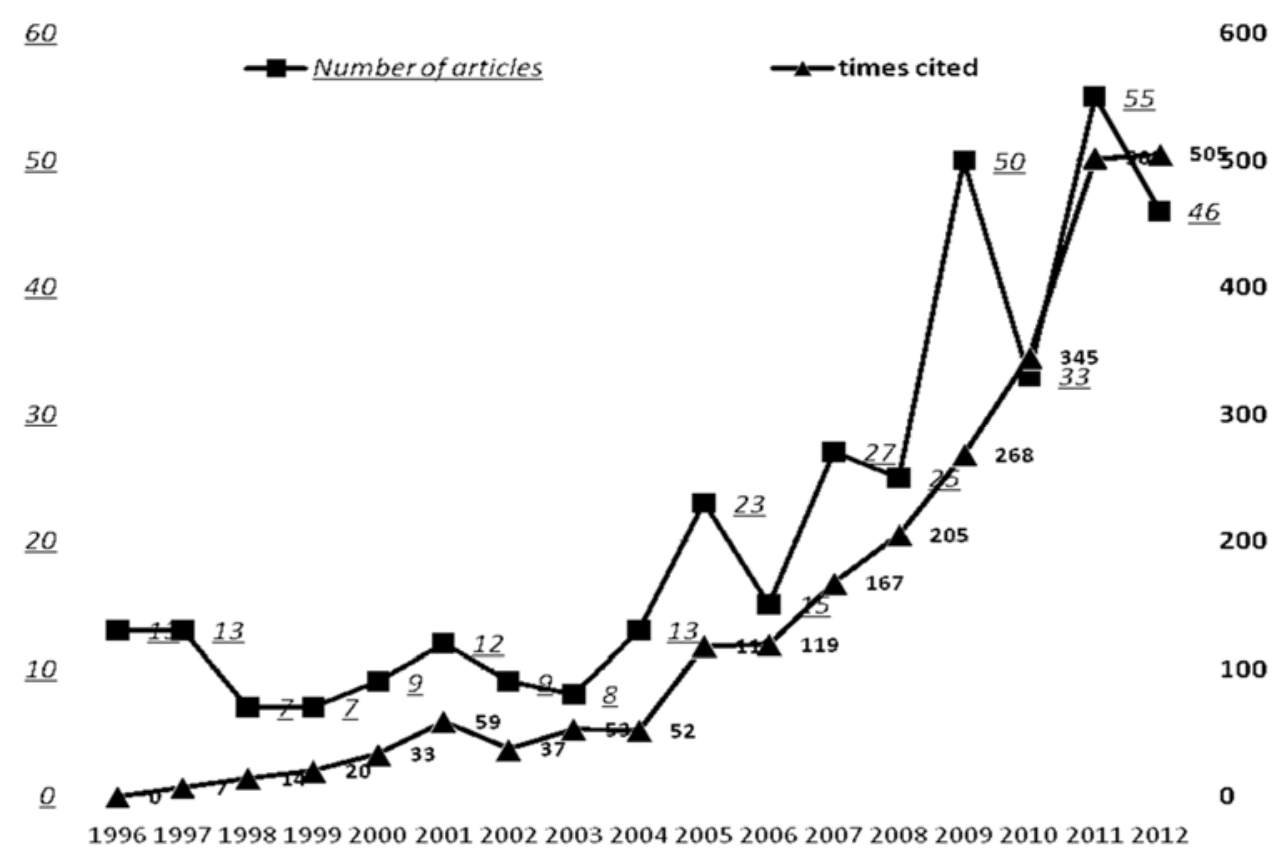

Fig. 1. Number of articles and times cited publications (1996-2012)

We searched the WOS database using keywords to locate 365 publications related to securitization in 47 academic journals from 1996 to 2012 (Figure 1). This study first explains the data-gathering methods and then presents the findings.

\section{Research Methods}

\subsection{Scope of the study}

We first conducted a keyword search in the WOS database using 10 securitization-related terms or keywords to identify a total of 365 securitization-related articles in 47 academic journals from 1996 to 2012. The following combinations of 15 keywords were used to search the article titles: MBS, mortgage backed, mortgage-backed, mortgage securitization, ABS, asset backed, asset-backed, asset securitization, CLO, collateralized loan obligation, $\mathrm{CMO}$, collateralized mortgage obligation, collateralized bond obligation, CDO, and collateralized debt obligation. Second, every article was reviewed by title, abstract, and content to ensure their relationship to securitization. Articles were then assigned to one of the eight subject areas 
shown in Table 1. "Business Economics" and "Urban Studies" are the two subject areas most related to securitization categorized by ISI WOS.

Table 1. Top Five Subject Area and numbers of articles (1996-2012)

\begin{tabular}{|c|c|c|}
\hline Subject Area & $\begin{array}{c}\text { Number of } \\
\text { articles }\end{array}$ & $\begin{array}{c}\text { \% of } \\
365 \text { articles }\end{array}$ \\
\hline 1. BUSINESS ECONOMICS & 344 & $93.9 \%$ \\
\hline 2. URBAN STUDIES & 106 & $28.9 \%$ \\
\hline 3. MATHEMATICAL METHODS IN SOCIAL SCIENCES & 19 & $5.2 \%$ \\
\hline 4. MATHEMATICS & 19 & $5.2 \%$ \\
\hline 5. OPERATIONS RESEARCH MANAGEMENT SCIENCE & 16 & $4.4 \%$ \\
\hline
\end{tabular}

\subsection{Assessment of authorial "contribution"}

To evaluate the authors' and individual publications' contributions to the field, we considered the "times cited" counts obtained from the ISI WOS database. The resulting measurement scale was used to determine the number of times an article was published and cited according to the ISI's WOS database [3]. Given that the author(s) of the article considered the cited works valuable to his/her own study and to the progress of their research field in general, the number of times a journal article was cited indicates its contribution [3], [5]. Consequently, the number of times that a published journal article was cited in the literature is fit to assess the influence that the particular article has had on the literature. Nonetheless, citation analysis conducted at various times results in a difference in opinion, such as bias for methodological articles or authors' extensive auto-citations. In the academic domain, citation analysis is usually acknowledged as a credible measure of an article's overall effect on the field. The effect (times cited) of every author on the 365 securitization research articles was obtained from the ISI WOS database.

\section{Research Results}

3.1 Frequency of securitization research in journals, country, and institution

Fig. 1 shows the complete number of articles on securitization published in academic journals as well as the times these articles were cited. The overall number of articles increased annually, and the growth trend value was calculated at 0.59 , which accounted for by a linear function.

We found 47 journals related to securitization research published between 1996 and 2012. These journals are presented in the upper part of Table 2 . Of the 365 articles related to securitization published in 47 journals from 1996 to $2012,38.1 \%$ appeared in the following "top-five" journals: (1) Journal of Real Estate Finance and Economics (43 articles or $11.8 \%$ ); (2) Real Estate Economics (30 articles or 8.2\%); (3) Journal of Banking Finance and Journal of Portfolio Management (each published 23 articles or $6.3 \%$ ); and (5) Journal of Financial Economics (20 articles or 5.5\%). Furthermore, 42 other journals published 1 to 19 articles related to securitization.

Table 2. Most frequent venues for SECURITIZATION publications among 47 journals (1996-2012.)

\begin{tabular}{|ll|c|c|}
\hline \multicolumn{1}{|c|}{ Journal title } & \# of articles & \% of total \\
\hline $\begin{array}{l}\text { 1. } \\
\text { NOURNAL OF REAL ESTATE FINANCE AND ECO- } \\
\text { NOMICS }\end{array}$ & 43 & $11.8 \%$ \\
\hline 2. & REAL ESTATE ECONOMICS & 30 & $8.2 \%$ \\
\hline
\end{tabular}




\begin{tabular}{|c|c|c|}
\hline 3. JOURNAL OF BANKING FINANCE & 23 & $6.3 \%$ \\
\hline JOURNAL OF PORTFOLIO MANAGEMENT & 23 & $6.3 \%$ \\
\hline 4. JOURNAL OF FINANCIAL ECONOMICS & 20 & $5.5 \%$ \\
\hline 5. 42 JOURNALS & $<20$ & $61.9 \%$ \\
\hline Country & \# of articles & $\%$ of total \\
\hline 1. USA & 248 & $58.2 \%$ \\
\hline 2. ENGLAND & 31 & $7.3 \%$ \\
\hline 3. CANADA & 15 & $3.5 \%$ \\
\hline 4. GERMANY & 13 & $3.1 \%$ \\
\hline 5. SINGAPORE & 12 & $2.8 \%$ \\
\hline 6. $\quad$ FRANCE & 10 & $2.3 \%$ \\
\hline NETHERLANDS & 10 & $2.3 \%$ \\
\hline PEOPLES R CHINA & 10 & $2.3 \%$ \\
\hline TAIWAN & 10 & $2.3 \%$ \\
\hline 7. 25 COUNTRIES & $<10$ & $15.7 \%$ \\
\hline
\end{tabular}

The lower part of Table 2 shows the top nine contributing countries, namely, the USA, England, Canada, Germany, Singapore, France, the Netherlands, People's Republic of China, and Taiwan. These countries published $84.3 \%$ of the 365 articles related to securitization. The six institutions, namely,
NBER, University of California-Berkeley, Stanford University, NYU, University of Connecticut, Harvard University, and the University of California-Los Angeles, published 93 articles, which accounted for $25.3 \%$ of the 365 articles (upper part of Table 3).

Table 3. Most Active Institutional Contributors and Researchers (1996-2012)

\begin{tabular}{|ll|c|c|}
\hline \multicolumn{1}{|c|}{ Institutional Contributors } & Number of articles & \% of 365 articles \\
\hline 1. & NBER & 22 & $6.0 \%$ \\
\hline 2. & UNIV CALIF BERKELEY & 15 & $4.1 \%$ \\
\hline 3. & STANFORD UNIV & 14 & $3.8 \%$ \\
\hline 4. & NYU. & 11 & $3.0 \%$ \\
\hline & UNIV CONNECTICUT. & 11 & $3.0 \%$ \\
\hline 5. & HARVARD UNIV & 10 & $2.7 \%$ \\
\hline 6. & UNIV CALIF LOS ANGELES & 10 & $2.7 \%$ \\
\hline 7. & 101 Institutions & $<10$ & $74.7 \%$ \\
\hline & $\quad$ Researcher & Number of articles & $\mathbf{\%}$ of $\mathbf{3 6 5}$ articles \\
\hline 1. & DENG, YH & 10 & $2.7 \%$ \\
\hline 2. & PASSMORE, W & 8 & $2.2 \%$ \\
\hline 3. & FABOZZI, FJ & 7 & $1.9 \%$ \\
\hline & LACOUR-LITTLE, M & 7 & $1.9 \%$ \\
\hline 5. & WALLACE, N & 6 & $1.6 \%$ \\
\hline & AMBROSE, BW & 5 & $1.4 \%$ \\
\hline & KAU, JB & 5 & $1.4 \%$ \\
\hline & LONGSTAFF, FA & 5 & $1.4 \%$ \\
\hline & ONG, SE & 5 & $1.4 \%$ \\
\hline
\end{tabular}




\begin{tabular}{|l|c|c|}
\hline SING, TF & 5 & $1.4 \%$ \\
\hline STANTON, R & 5 & $1.4 \%$ \\
\hline 12. 87 authors & $<5$ & $81.4 \%$ \\
\hline \multicolumn{2}{|r|}{ Total Authors: 98} \\
\hline
\end{tabular}

3.2 Primary individual contributors and most frequently published credited authors on securitization

Among the authors of the 365 articles, 11 were found to have published their work in five or more publications, and 87 published their work in less than five publications from 1996 to 2012 (lower part of Table 3). The top 11 authors who published articles related to securitization are as follows: Deng (10 publications); Passmore (8 publications); Fabozzi and Lacour-Little (7 publications each); and
Wallace, Ambrose, Kau, Longstaff, Ong, Sing, and Stanton (5 publications each).

\subsection{Most frequently cited securitization arti-} cles

The 365 securitization research articles were ranked based on their total WOS citations as posted on the ISI WOS database to find the most-cited article. Table 4 lists the most-cited securitization articles published between 1996 and 2012, including the authors, number of times the titles were cited, and journal name.

Table 4. The top-five and other most frequently-cited SECURITIZATION articles (19962012)

\begin{tabular}{|c|c|c|c|c|}
\hline Rank & Authors & Times Cited & Article title & Journal \\
\hline 1 & $\begin{array}{l}\text { Brav, A; } \\
\text { Gompers, PA. } \\
(1997)\end{array}$ & 227 & $\begin{array}{l}\text { Myth or Reality The Long-Run Un- } \\
\text { derperformance of Initial Public Of- } \\
\text { ferings- Evidence from Venture and } \\
\text { Nonventure Capital-Backed Compa- } \\
\text { nies }\end{array}$ & $\begin{array}{l}\text { JOURNALOF } \\
\text { FINANCE } \\
\end{array}$ \\
\hline 2 & $\begin{array}{l}\text { Campbell, } \\
\text { John Y. (2006) }\end{array}$ & 141 & Household finance & $\begin{array}{l}\text { JOURNAL OF } \\
\text { FINANCE }\end{array}$ \\
\hline 3 & $\begin{array}{l}\text { Fung, W; } \\
\text { Hsieh, DA } \\
(2004)\end{array}$ & 78 & $\begin{array}{l}\text { Hedge fund benchmarks: A risk-based } \\
\text { approach }\end{array}$ & $\begin{array}{c}\text { FINANCIAL } \\
\text { ANALYSTS } \\
\text { JOURNAL }\end{array}$ \\
\hline 4 & $\begin{array}{l}\text { Duffie, D; } \\
\text { Garleanu, N } \\
(2001)\end{array}$ & 76 & $\begin{array}{l}\text { Risk and valuation of collateralized } \\
\text { debt obligations }\end{array}$ & $\begin{array}{c}\text { FINANCIAL } \\
\text { ANALYSTS } \\
\text { JOURNAL }\end{array}$ \\
\hline 5 & $\begin{array}{l}\text { DeMarzo, PM } \\
(2005)\end{array}$ & 51 & $\begin{array}{l}\text { The pooling and tranching of securi- } \\
\text { ties: A model of informed intermedia- } \\
\text { tion }\end{array}$ & $\begin{array}{c}\text { REVIEW OF } \\
\text { FINANCIAL } \\
\text { STUDIES }\end{array}$ \\
\hline & 360 articles & \multicolumn{3}{|c|}{ Times Cited $<50$} \\
\hline
\end{tabular}

The article "Myth or Reality? The Long-Run Underperformance of Initial Public Offerings: Evidence from Venture and Nonventure Capital-Backed Companies" [1] investigated the long-term underperformance of recent initial public offering (IPO) firms in a sample of 934 venture-backed IPOs from 1972 to 1992 and 3,407 non-venture-backed IPOs from 1975 to 1992 . Using equal weighted re- turns, the authors found that venture-backed IPOs perform better than non-venture-backed IPOs. This article was cited 227 times and ranked first.

The article "Household Finance" [2] argued that household finance is a challenging issue because household behavior is difficult to measure, and households face constraints not captured by textbook models. Campbell 
found evidence on participation, diversification, and mortgage refinancing and suggested that many households invest effectively, except a minority that commits significant mistakes. This minority is poorer and less educated than the majority of the more successful investors. Evidence showed that the households are aware of their own limitations and opt to avoid from financial strategies that they feel unqualified. Certain financial products involve a cross-subsidy from naïve to sophisticated households, which can inhibit welfare-improving financial innovation. This article ranked second and cited 141 times.

The article "Hedge fund benchmarks: A riskbased approach" [8] focused on the data and methodological difficulties encountered in applying conventional models of constructing asset-class indices for hedge funds and argued against the conventional approach. The authors extended and proposed an APTlike model of hedge fund returns with dynamic risk factor coefficients. For the diversified hedge fund portfolios, the seven ABS style factors explained up to $90 \%$ of monthly return variations. ABS factors are directly observable using market prices. Their model provided a standardized framework to identify the differences among major hedge fund indices. Their proposed framework was free from biases inherent in hedge fund databases. In addition, the time-varying behavior of alternative alphas and betas revealed important insight on how funds-of-hedge funds alter their bets over time. This article was cited 78 times and ranked third.

The article "Risk and valuation of collateralized debt obligations" [7] provided risk analysis and market valuation of collateralized debt obligations (CDOs). It demonstrates the effects of correlation and prioritization for market valuation, diversity score, and risk of CDOs in a simple jump-diffusion setting for correlated default intensities. This article was cited 76 times and ranked fourth.

The article "The pooling and trenching of securities: a model of informed intermediation" [6] showed that when the intermediary has superior information on the value of each asset, the intermediary is better off selling shares in the assets as an individual rather than as part of a pool. Specifically, pooling has an information destruction effect that works to the disadvantage of the intermediary by preventing the intermediary from fully exploiting information regarding each asset. This article was cited 51 times and ranked fifth.

\section{Conclusion and Limitation}

This study assesses the contributions of individual and institutional contributors to the research on securitization from 1996 to 2012. We identified 365 studies of acceptable rigor, credibility, and relevance. The effect of individual articles and authors on securitization literature was also assessed based on SCI and SSCI citation analyses. The implications of this study are discussed below, with the objective of presenting some conclusions on securitization studies.

First, securitization research has attracted numerous researchers in a span of 14 years, which was covered in this study. Researchers from North America (USA and Canada), Europe (England, Germany, France, and Netherlands), and Asia (Singapore, People's Republic of China, and Taiwan) contributed mostly to this field. We conclude that the more developed an area, the more scholars will investigate on securitization.

Second, the journals that published the largest numbers of research articles on securitization were the Journal of Real Estate Finance and Economics, Real Estate Economics, Journal of Banking Finance, Journal of Portfolio Management, and Journal of Financial Economics.

Third, the primary contributors emerged in the field from 1996 to 2012. The studies had an important effect on researchers of securitization. New scholars in this field would benefit from the published articles.

Finally, this study showed that the number of academic articles that covered the academic field of securitization from 1996 to 2012 is increasing. This finding indicates that the influence of securitization is still rising. Thus, we hope that these findings can help authors in their research on the development of secu- 
ritization. With regard to the limitation of this study, we used computer programs to gauge trends and contributions to the broad field of securitization. Certain researchers may argue that this paper is a project to select relevant studies on securitization and may not fully related to securitization. Some may also consider that the findings (for example, the most frequently cited journal articles for SECURITIZATION) are common to securitization academics or a practitioner. We believe that new scholars will benefit from the securitization articles listed in this study.

\section{References}

[1] A. Brav, P.A. Gompers, Myth or Reality The Long-Run Underperformance of Initial Public Offerings- Evidence from Venture and Nonventure Capital-Backed Companies, Journal of Finance 52(5), 1997, pp. 1791-1821.

[2] J.Y. Campbell, Household finance, Journal of Finance 61(4), 2006, pp. 15531604.

[3] P. Chandy and T. Williams, The impact of journals and authors on international business research: a citational analysis of JIBS articles, Journal of International Business Studies. 25, 1994, pp. 715-728.

[4] P.L. Cooley and J.L. Heck, "Significant contributions to finance literature." Financial Management 10 (2), 1981, pp. 25-35.

[5] J. Cote, S. Leong, Assessing the influence of Journal of Consumer Research: A citation analysis. Journal of Consumer Research. 18, 1991, pp. 402-410.

[6] P.M. DeMarzo, "The pooling and tranching of securities: A model of informed intermediation", REVIEW OF FINANCIAL STUDIES 18(1), 2005, pp. 1-35

[7] D. Duffie, N. Garleanu, The pooling and tranching of securities: A model of informed intermediation, Financial Ana- lysts Journal 57(1), 2001, pp. 41-59.

[8] W. Fung, D.A. Hsieh, "Hedge fund benchmarks: A risk-based approach", FINANCIAL ANALYSTS JOURNAL 60(5), 2004, pp. 65-80.

[9] P. E. Graves, R. J. Marchand and T. Randall, "Economics Departmental Rankings: Research Incentives, Constraints, and Efficiency." American Economic Review 72 (5), 1982, pp. 1131-1141.

[10] J.L. Heck, L. P. Cooley and C.M. Hubbard, "Contributing Authors and Institutions to the Journal of Finance: 19461985." Journal of Finance 41 (5), 1986, pp. 1129-1140.

[11] C. Latchem, A content analysis of the British Journal of Educational Technology. British Journal of Educational Technology. 37, 2006, pp. 503-511.

[12] L. Tainyi, R.E. Johanson, L. Hsipeng, L. $\mathrm{Wu}$, Trends and Lacunae for Future Computer Assisted Learning (CAL ) Research: An Assessment of the Literature in SSCI Journals from 1998-2006, Journal of the American Society for Information Science and Technology, 59(8), 2008, pp. 1313-1320.

[13] C. MacArthur, R. Ferretti, C. Okolo and A. Cavalier, Technology applications for students with literacy problems: a critical review. The Elementary School Journal. 101, 2001, pp. 273-302.

[14] J. Sa-Aadu and J. D. Shilling, "Rankings Of Contributing Authors The AREUEA Journal By Doctoral origin and employer 1973-1987." Journal of the American Real Estate \& Urban Economics Association 16(3), 1988, pp. 257-270.

[15] S. Zou, Contributions to international advertising research: an assessment of the literature between 1990 and 2002. Journal of Advertising. 34, 2005, pp. 99-110. 


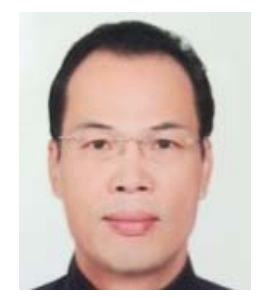

King Jeng $\mathbf{L U}$ is a Ph.D. student in the Department of Information Management and the Dean of the National Taiwan University of Science and Technology (Taipei, Taiwan, R.O.C.).

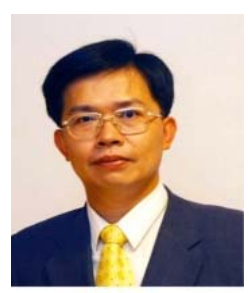

Tainyi LUOR is a part time Associate Professor in the National Taiwan University of Science and Technology Graduate School of Management (Taipei, Taiwan, R.O.C.) and General Manager of the Information Management at the International Bills Finance Corporation. His research interests involve the implementation of CAL applications into financial management issues and web-based business applications.

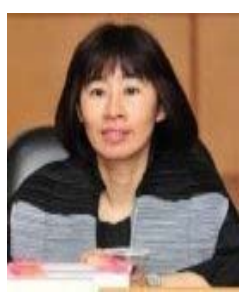

Liang, CHIUNG-JU is Chair Professor (Foxlink) of Graduate Institute of Finance, Chair Professor (Epson) of Graduate Institute of Finance and Chairperson of Graduate Institute of Finance, NTUST(2010/08 ).

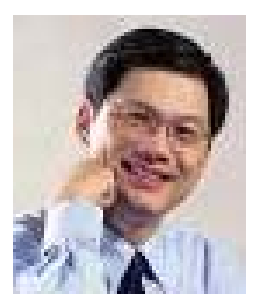

Hsi-peng $\mathbf{L U}$ is a Professor in the Department of Information Management and the Dean of the National Taiwan University of Science and Technology (Taipei, Taiwan, R.O.C.) 